\title{
Pencapaian pemahaman orang tua dalam membimbing tata krama anak autis
}

\author{
Dian Ngesti Swandari *, Mumpuniarti Mumpuniarti \\ Program Studi Pendidikan Luar Biasa, Pascasarjana, Universitas Negeri Yogyakarta. \\ Jalan Colombo No. 1, Yogyakarta, 55281, Indonesia \\ *Corresponding Author. Email: dian.swandari@gmail.com
}

Received: 22 May 2019; Revised: 4 July 2019; Accepted: 30 January 2020

\begin{abstract}
Abstrak: Tata krama merupakan bagian dari keterampilan sosial yang mengajarkan sikap baik dalam pergaulan dari segi bahasa maupun tingkah laku. Tata krama perlu diperkenalkan pada anak autis agar mereka dapat membedakan perilaku baik dan perilaku yang kurang tepat untuk dilakukan. Orang tua memegang peranan penting dalam membimbing tata krama anak autis. Oleh karena itu diupayakan agar orang tua memahami cara untuk mendampingi dan membimbing tata krama anak autis. Salah satu cara yang efektif dalam pendampingan latihan tata krama anak autis adalah dengan pembelajaran observasional, di mana orang tua berperan sebagai model atau contoh yang akan ditiru oleh anak autis. Adapun tujuan dari latihan tata krama dengan pembelajaran observasional ini adalah agar anak berlatih tata krama dengan melihat orang tua sebagai model kemudian anak berlatih tata krama berdasar apa yang dilihatnya pada orang tua. Jadi orang tua memiliki peran ganda yaitu sebagai model dan pendamping latihan sehingga orang tua dapat memahami fungsi dari peran orang tua anak autis. Metode yang digunakan dalam penelitian ini adalah penelitian tindakan yang melibatkan semua pihak secara langsung dan dimaksudkan untuk meningkatkan keterampilan pada semua pihak yang terlibat. Kata Kunci: anak autis, peran orang tua, pembelajaran observasional, tata krama
\end{abstract}

\section{The achievement of parents comprehension in guiding autism children manners}

\begin{abstract}
Manners are parts of social skills that teach good attitude in association in terms of language and behavior. Manners need to be introduced to autistic children so that they can distinguish between good behavior and inappropriate behavior to do. Parents play an important role in guiding the manners of autistic children. Therefore efforts are made so that parents understand how to assist and guide the behavior of autistic children. One effective way of mentoring autism practices for children with autism is observational learning, where parents act as models or examples that will be imitated by autistic children. The aim of this observational learning is that children can practice manners by seeing their parents as models and at the end they can apply what they see from their parents. Therefor, parents have two roles, that are as a model and a training companion so that parents can understand the role function of parents of children with autism. The method used in this research is action research that involves all parties directly and intended to improve the skills of all parties involved.
\end{abstract}

Keyword: autistic children, parental role, observational learning, manners

How to Cite: Swandari, D., \& Mumpuniarti, M. (2020). Pencapaian pemahaman orang tua dalam membimbing tata krama anak autis. JPPM (Jurnal Pendidikan dan Pemberdayaan Masyarakat), 7(1), 57-64. doi:https://doi.org/10.21831/jppm.v7i1.25036

\section{PENDAHULUAN}

Tata krama adalah bagian dari kajian keterampilan sosial. Keterampilan sosial merupakan bagian penting dari kemampuan hidup manusia dalam mengadakan hubungan dengan orang lain sehingga memperoleh hubungan yang harmonis dalam masyarakat. Salah satu bagian dari keterampilan sosial yang perlu untuk diperkenalkan pada anak sejak usia dini adalah tata krama 


\section{JPPM (Jurnal Pendidikan dan Pemberdayaan Masyarakat), 7 (1), 2020 - 58}

Dian Ngesti Swandari, Mumpuniarti Mumpuniarti

agar perilaku santun terbentuk dari masa kanak-kanak sehingga dalam kehidupan bermasyarakat seorang anak mampu untuk menunjukkan perilaku positif. Hal ini diungkapkan oleh Inbar dan Meyer (2019) bahwa mengajarkan sikap dan perilaku yang baik pada anak adalah penting untuk perkembangan sosial dan kognitif, perilaku santun akan menghasilkan pengendalian sosial, cara pandang dan karakter yang kuat.

Tata krama juga perlu diajarkan pada anak autis agar anak autis dapat membedakan perilaku yang boleh untuk dilakukan dan perilaku yang kurang tepat untuk dilakukan. Umumnya anak autis sulit untuk melakukan kontak mata dan kurang dapat menangkap sinyal sosial sehingga mereka tidak dapat merespon seperti yang diharapkan, misalkan senyum dibalas senyum (Nugraheni, 2008, p. 64). Karakter anak autis yang kurang dapat merespon sinyal sosial ini juga diungkapkan oleh Okada et al. (2010) bahwa anak autis mengalami kesulitan dalam memahami aturan sosial oleh karena itu dibutuhkan pengajaran perilaku baik pada anak autis. Hal ini juga diungkapkan oleh Delphie (2009, p. 16) bahwa pemahaman sosial anak autis mengalami hambatan karena mereka tidak menaruh perhatian pada tanda emosional dan perhatian orang lain. Oleh karena itu akan lebih baik bila dilakukan latihan keterampilan sosial pada anak autis agar pemahaman sosial mereka lebih baik. Hal ini didukung oleh pendapat dari Lordo et al. (2017) yang mengatakan bahwa keefektifan sebuah latihan keterampilan sosial pada seorang autis dapat membantu seorang autis dapat berpartisipasi dalam kehidupan sosial.

Oleh karena itu diperlukan pengenalan dan latihan kegiatan tata krama pada anak autis agar mereka dapat memunculkan perilaku yang tepat dalam suatu kondisi. Salah satu cara yang efektif untuk membimbing anak autis dalam latihan tata krama adalah dengan pembelajaran observasional. Inti dari pembelajaran observasional adalah pemodelan (modeling). Melalui belajar mengamati yang untuk selanjutnya disebut imitasi atau modeling, individu secara kognitif menampilkan tingkah laku orang lain yang diamati dan mengadopsi tingkah laku tersebut dalam dirinya sendiri (Desmita, 2012, p. 58). Berpegang pada prinsip utama dari teori pembelajaran observasional yaitu pemodelan (modeling) maka teknik modeling yang diterapkan dalam pembelajaran dapat dilakukan di dalam lingkungan keluarga dan dalam hal ini orang tua memiliki peran ganda sebagai model (contoh) sekaligus pembimbing belajar. Halle et al. (2016) mengungkapkan bahwa perlu adanya model yang dapat dilihat langsung oleh anak autis tentang perilaku yang baik agar anak autis dapat menirukan perilaku yang baik itu hingga menjadi suatu kebiasaan. Dalam pembelajaran dengan pemodelan, perpaduan antara perhatian, contoh yang nyata dan penghargaan merupakan lingkungan yang tepat untuk mendorong munculnya perilaku yang diharapkan, dalam artian proses pendidikan semacam ini akan membentuk dan menanamkan perilaku positif yang diharapkan dalam pikiran anak (Anwar, 2017, pp. 106-107).

Orang tua merupakan pendidik pertama dan utama bagi seorang anak. Orang tua memiliki dua tugas dalam perannya sebagai pendidik yaitu tugas dalam bidang pembentukan kemanusiaan dan tugas dalam bidang kemasyarakatan (Helmawati, 2017, pp. 22-28). Dalam bidang pembentukan kemanusiaan, orang tua dituntut untuk memiliki lima tugas penting yaitu (1) tugas memelihara anak sejak dalam kandungan ibu, (2) tugas mendidik dengan memberikan ajaran untuk kecerdasan pikiran, (3) tugas membina yang berarti bertugas membentuk karakter anak, (4) tugas membimbing dengan melatih anak untuk membentuk perilaku baik, (5) tugas melatih untuk mengarahkan anak agar mampu mengerjakan apa yang sudah dipelajari secara terampil. Dalam bidang kemasyarakatan, orang tua mengajarkan pada anak tentang manusia sebagai mahluk sosial dalam artian manusia tidak dapat hidup sendiri dan membutuhkan orang lain dalam hidup sehingga pada anak diajarkan tentang interaksi sosial dan life skill. Bagi anak autis diperlukan contoh atau model dalam mempelajari tata krama karena anak autis memiliki hambatan dalam memahami apa yang dipikirkan orang lain dan model yang baik bagi anak autis adalah keluarganya. Pendapat tentang pentingnya keterlibatan keluarga ini juga dikemukakan oleh Setyaningrum et al. (2018, p. 48) bahwa kemampuan sosial anak autis akan mengalami perkembangan bila mendapat dukungan dan perhatian khusus dari orang di dekat anak dan dalam mempelajari kemampuan sosial, model atau teladan sangat penting untuk anak autis. 
Dalam penelitian ini dibutuhkan peran orang tua dalam melatih materi tata krama pada anak autis dan subjek dalam penelitian ini adalah orang tua siswa autis yang tidak memiliki hambatan bicara. Orang tua akan berperan sebagai model dengan menyajikan perilaku yang baik sesuai materi tata krama yang diajarkan dan anak akan diminta memperhatikan dan selanjutnya menirukan perilaku yang dicontohkan oleh orang tua. Oleh karena itu dibutuhkan pemahaman orang tua dalam cara melatih tata krama pada anak autis.

Penelitian ini bertujuan untuk meningkatkan pemahaman orang tua dalam melatih tata krama dengan menerapkan orang tua sebagai model tentang perilaku tata krama. Adanya pemahaman yang baik tentang cara melatih tata krama akan memacu orang tua untuk menstimulasi anak agar dapat memunculkan perilaku baik.

\section{METODE}

Penelitian ini merupakan penelitian tindakan dengan pendekatan kualitatif yang datadatanya diperoleh melalui pengamatan dan wawancara yang dikemas dalam bentuk deskriptif. Dalam metode ini diungkapkan kejadian atau keadaan yang terjadi saat penelitian berlangsung dengan menyuguhkan apa yang sesbenarnya terjadi. Penelitian yang akan dilakukan dimaksudkan untuk meningkatkan pemahaman orang tua dalam melatih tata krama pada anak autis dan membantu anak autis dalam berlatih tata krama melalui teknik pembelajaran observasional di mana dalam teknik ini terdapat tahap atensi yaitu perhatian pada model, tahap retensi yaitu menyimpan informasi dari kegiatan memperhatikan tadi dalam ingatan, tahap reproduksi yaitu melakukan kegiatan seperti yang diamati dan tahap motivasi yaitu penggerak untuk terus melakukan kegiatan seperti yang diamati. Penelitian dilaksanakan di kota Klaten pada September November 2019.

Subjek dalam penelitian ini adalah orang tua yang memiliki anak autis yang tidak memiliki hambatan bicara dan jumlah subjek ada 15 orang. Subjek merupakan orang tua dari anak autis yang bersekolah di SLB Autis Lentera Harapan Klaten.

Penelitian diawali dengan wawancara yang bertujuan untuk mengetahui seberapa jauh langkah yang telah dilakukan orang tua dalam memberikan bimbingan tata krama. Selain dilakukan wawancara juga dilakukan observasi atau pengamatan langsung pada cara orang tua dalam memberikan bimbingan tata krama pada anak autis. Observasi ini dilakukan secara langsung bagaimana proses orang tua dalam memberikan bimbingan tata krama dan materi tata krama yang diberikan pada anak. Dari observasi ini juga dapat dilihat apa yang menjadi kesulitan orang tua dalam memberikan bimbingan tata krama. Berikut ini adalah kisi-kisi instrumen yang berkaitan dengan tingkat pencapaian pemahaman orang tua dalam membimbing tata krama anak autis (Tabel 1 ).

Tabel 1. Tingkat Pencapaian Pemahaman Orang Tua dalam Membimbing Tata Krama pada Anak Autis

\begin{tabular}{|c|c|}
\hline Aspek & Indikator \\
\hline Permodelan & 1. Konsisten \\
\hline Interaksi & $\begin{array}{l}\text { 2. Contoh yang mudah } \\
\text { 1. Komunikasi yang kontinyu } \\
\text { 2. Kejelasan instruksi }\end{array}$ \\
\hline
\end{tabular}

Penelitian ini merupakan penelitian tindakan dengan menggunakan Siklus I dan Siklus II. Dalam setiap siklus dilakukan tahap perencanaan, pelaksanaan, pengamatan dan refleksi.

\section{HASIL DAN PEMBAHASAN}

Pada siklus I dalam tahap perencanaan, penulis bekerja sama dengan 15 orang tua yang menjadi subjek serta satu guru dari SLB Autis Lentera Harapan Klaten berdiskusi untuk persiapan pelaksanaan. Penelitian dilakukan di SLB Autis Lentera Harapan Klaten setelah jam belajar. Pada tahap perencanaan, penulis membuat rancangan kegiatan yang berisi tujuan, materi dan teknik pelaksanaan. Materi tata krama yang diberikan pada penelitian ini ada lima yaitu (1) 
bersalaman, (2) mengetuk pintu, (3) menutup mulut saat batuk atau menguap, (4) mengucapkan minta tolong, (5) mengucapkan terima kasih.

Orang tua harus dapat memahami tujuan dari tiap materi tata krama tersebut agar dalam memberikan bimbingan dan arahan kegiatan tata krama pada anak, tetap fokus pada bagian yang menjadi tujuan utama tiap materi. Tujuan dari materi (1) bersalaman adalah agar anak menjadi peka terhadap kehadiran orang lain, (2) mengetuk pintu adalah agar anak belajar menahan diri untuk tidak menerobos pintu tertutup, (3) menutup mulut saat batuk atau menguap adalah agar anak peka terhadap lingkungan sekitarnya, (4) mengucapkan minta tolong agar anak dapat melakukan komunikasi sederhana dengan orang lain dan mengendalikan diri untuk mendapatkan keinginannya, (5) mengucapkan terima kasih agar anak dapat melakukan komunikasi sederhana dengan orang lain dengan memberikan respon yang tepat.

Teknik yang digunakan dalam kegiatan latihan tata krama ini adalah teknik dalam pembelajaran observasional di mana inti dari pembelajaran ini adalah pemodelan (modeling). Orang tua menjadi contoh bagi anak dalam berlatih tata krama. Oleh karena itu perlu ditekankan peran orang tua selain memahami tujuan dari tiap materi tata krama juga harus dapat memberikan contoh yang mudah untuk dipahami anak. Berikut ini adalah langkah-langkah yang dilakukan dalam kegiatan melatih tata krama dengan menggunakan teknik pembelajaran observasional (Tabel 2).

Tabel 2. Latihan Bersalaman

\begin{tabular}{|c|c|c|}
\hline 1. & Atensi & $\begin{array}{l}\text { a. Orang tua dan anak berhadapan } \\
\text { b. Orang tua mengajak anak bersalaman }\end{array}$ \\
\hline 2. & Retensi & $\begin{array}{l}\text { a. Pegang tangan anak, beri contoh bersalaman } \\
\text { b. Ulangi latihan bersalaman }\end{array}$ \\
\hline 3. & Reproduksi & $\begin{array}{l}\text { a. Ajak anak bersalaman, tanpa diberi contoh } \\
\text { b. Perbaiki kekeliruan gerakan }\end{array}$ \\
\hline 4. & Motivasi & $\begin{array}{l}\text { a. Orang tua mengajak anak bersalaman } \\
\text { b. Beri pujian bila melakukan dengan tepat }\end{array}$ \\
\hline
\end{tabular}

Pada latihan bersalaman ini ditemukan bahwa 15 subjek orang tua dapat memberikan contoh yang mudah pada anak dan orang tua melakukan dengan konsisten sehingga anak dapat mengikuti dengan mudah. Pada latihan bersalaman ini ditemukan semua anak merespon dan menirukan gerakan bersalaman dengan baik. Untuk beberapa anak pada awal latihan masih memerlukan instruksi dan untuk selanjutnya anak dapat menirukan dengan baik.

Tabel 3. Latihan Mengetuk Pintu

\begin{tabular}{lll}
\hline 1. & Atensi & a. Ajak anak berdiri di depan pintu \\
& & b. Orang tua memberi contoh ketuk pintu \\
2. Retensi & a. Bantu membentuk jari untuk posisi mengetuk \\
& & b. Ulangi latihan mengetuk pintu \\
3. Reproduksi & a. Anak mengetuk pintu tanpa dibantu \\
4. Motivasi & b. Perbaiki saat terjadi kekeliruan \\
& & a. Anak mengetuk pintu \\
\end{tabular}

Pada latihan mengetuk pintu ini (Tabel 3 ), 15 subjek orang tua dapat memberi contoh yang mudah dalam mengetuk pintu. Pada latihan mengetuk pintu ini ditemukan 4 subjek orang tua yang masih memberikan instruksi agar anak melakukan gerakan mengetuk dan tidak mengetuk dengan keras-keras. Pada subjek orang tua lainnya, anak dapat menirukan gerakan dengan baik dan hanya perlu diberi instruksi agar mengetuk pintu agak keras.

Pada latihan menutup mulut saat batuk atau menguap ini (Tabel 4), 15 subjek orang tua memberi contoh secara berulang dan anak diminta melakukan gerakan bersama-sama dengan orang tua dan setelah diberikan contoh 14 anak dapat menirukan dengan baik. Pada latihan menutup mulut saat batuk atau menguap ini ditemukan 1 subjek orang tua yang masih memerlukan 
JPPM (Jurnal Pendidikan dan Pemberdayaan Masyarakat), 7 (1), 2020 - 61

Dian Ngesti Swandari, Mumpuniarti Mumpuniarti

instruksi agar anak dapat menggunakan tangan dengan tepat di depan mulut dan untuk selanjutnya anak dapat melakukan dengan baik.

Tabel 4. Latihan Menutup Mulut Saat Batuk Atau Menguap

\begin{tabular}{lll}
\hline 1. & Atensi & $\begin{array}{l}\text { a. Orang tua dan anak berhadapan } \\
\text { b. Orang tua memberi contoh menutup mulut saat batuk atau menguap } \\
\text { a. Bantu anak menggunakan tangannya dengan tepat untuk menutup mulut } \\
\text { b. Ulangi latihan menutup mulut saat batuk atau menguap }\end{array}$ \\
2. Retensi & $\begin{array}{l}\text { a. Anak menutup mulut saat batuk atau menguap tanpa dibantu } \\
\text { b. Perbaiki bila terjadi kekeliruan gerakan }\end{array}$ \\
3. Reproduksiak & $\begin{array}{l}\text { a. Anak menutup mulut saat batuk atau menguap } \\
\text { b. Beri pujian bila melakukan dengan tepat }\end{array}$ \\
\hline
\end{tabular}

Tabel 5. Latihan Mengucapkan Minta Tolong

\begin{tabular}{|c|c|c|}
\hline 1. & Atensi & $\begin{array}{l}\text { a. Orang tua berperan minta tolong untuk mengambil sebuah buku pada anak } \\
\text { b. Orang tua mengucapkan, "Minta tolong ambilkan buku itu" }\end{array}$ \\
\hline 2. & Retensi & $\begin{array}{l}\text { a. Bantu anak mengucapkan minta tolong untuk mengambil buku } \\
\text { b. Ulangi latihan mengucap minta tolong }\end{array}$ \\
\hline 3. & Reproduksi & $\begin{array}{l}\text { a. Ingatkan anak mengucap minta tolong pada orang lain untuk mengambil sebuah } \\
\text { benda } \\
\text { b. Anak mengucap minta tolong tanpa diberi bantuan }\end{array}$ \\
\hline 4. & Motivasi & $\begin{array}{l}\text { a. Anak mengucap minta tolong untuk mengambil sebuah benda } \\
\text { b. Beri pujian bila melakukan dengan tepat }\end{array}$ \\
\hline
\end{tabular}

Pada latihan mengucapkan minta tolong ini (Tabel 5), 15 subjek orang tua memerlukan waktu untuk membantu mengucapkan minta tolong. Pada latihan mengucapkan minta tolong ini ditemukan 7 subjek orang tua yang masih mengingatkan anak untuk mengucapkan minta tolong, karena ada anak yang cenderung mengatakan "ambilkan" atau "itu". Pada 8 subjek orang tua, anak dapat menirukan pengucapan minta tolong dengan beberapa kali contoh. Untuk selanjutnya, anak dapat melakukan dengan baik.

Tabel 6. Latihan Mengucapkan Terima Kasih

\begin{tabular}{|c|c|c|}
\hline 1. & Atensi & $\begin{array}{l}\text { a. Orang tua meminta anak mengambil sebuah buku } \\
\text { b. Orang tua mengucap terima kasih saat buku diberikan }\end{array}$ \\
\hline 2. & Retensi & $\begin{array}{l}\text { a. Bantu anak mengucapkan terima kasih saat diberi buku } \\
\text { b. Ulangi latihan mengucap terima kasih }\end{array}$ \\
\hline 3. & Reproduksi & $\begin{array}{l}\text { a. Ingatkan anak untuk tidak lupa mengucap terima kasih } \\
\text { b. Tanpa dibantu, anak mengucap terima kasih saat diberi buku }\end{array}$ \\
\hline 4. & Motivasi & $\begin{array}{l}\text { a. Anak mengucapkan terima kasih saat diberi sebuah benda } \\
\text { b. Beri pujian bila melakukan dengan tepat }\end{array}$ \\
\hline
\end{tabular}

Pada latihan mengucapkan terima kasih (Tabel 6), 15 subjek orang tua memberi contoh berulang agar anak dapat memahami. Pada latihan mengucapkan terima kasih ini ditemukan 2 subjek orang tua yang masih perlu memberikan instruksi agar anak dapat melakukan. Pada 13 anak, saat awal masih dipandu untuk mengucapkan terima kasih ketika diberi sebuah benda. Untuk selanjutnya anak dapat menirukan dan melakukan dengan baik.

Tabel pencapaian orang tua dalam memberikan latihan tata krama pada siklus 1 dapat dilihat pada Tabel 7. Indikator tingkat pencapaian pemahaman orang tua dalam membimbing tata krama pada anak autis yang harus dicapai dalam siklus I ini adalah (1) orang tua dapat memberikan contoh yang konsisten, (2) orang tua dapat memberikan instruksi yang jelas, (3) orang tua terus melakukan komunikasi dengan anak tentang tujuan tiap materi, (4) orang tua memiliki inisiatif untuk memberi contoh yang mudah dimengerti anak.

Pada tahap pelaksanaan siklus I, 15 orang tua yang menjadi subjek berperan sebagai model latihan tata krama, 15 anak dari orang tua tersebut diminta untuk memperhatikan contoh yang diberikan. Guru berperan mendampingi anak untuk membantu anak dalam merespon. Penulis 
berperan sebagai pengamat yang mencatat dan mengamati proses latihan tata krama dengan pembelajaran observasional yang dilakukan oleh orang tua dan melihat respon yang dimunculkan oleh anak. Pelaksanaan siklus I ini dilakukan pada 9 September sampai 11 Oktober 2019 dengan alokasi waktu 6o menit dengan pertimbangan ada jeda waktu bila anak mengalami kebosanan atau faktor lain yang menyebabkan anak tidak dapat fokus mengikuti.

Tabel 7. Pencapaian Orang Tua dalam Latihan Tata Krama

\begin{tabular}{clllll}
\hline \multirow{2}{*}{ Subjek Orang Tua } & \multicolumn{5}{c}{ Respon Anak } \\
\cline { 2 - 5 } OT 1 & Menirukan & Menirukan & Menirukan & Menirukan & Menirukan \\
OT 2 & Menirukan & Dibantu & Menirukan & Dibantu & Menirukan \\
OT 3 & Menirukan & Menirukan & Menirukan & Dibantu & Dibantu \\
OT 4 & Menirukan & Menirukan & Menirukan & Dibantu & Menirukan \\
OT 5 & Menirukan & Menirukan & Menirukan & Menirukan & Menirukan \\
OT 6 & Menirukan & Menirukan & Menirukan & Menirukan & Menirukan \\
OT 7 & Menirukan & Dibantu & Menirukan & Menirukan & Dibantu \\
OT 8 & Menirukan & Menirukan & Menirukan & Dibantu & Menirukan \\
OT 9 & Menirukan & Dibantu & Menirukan & Dibantu & Menirukan \\
OT 10 & Menirukan & Menirukan & Menirukan & Menirukan & Menirukan \\
OT 11 & Menirukan & Menirukan & Dibantu & Dibantu & Dibantu \\
OT 12 & Menirukan & Menirukan & Menirukan & Menirukan & Menirukan \\
OT 13 & Menirukan & Dibantu & Menirukan & Dibantu & Dibantu \\
OT 14 & Menirukan & Menirukan & Menirukan & Menirukan & Menirukan \\
OT 15 & Menirukan & Menirukan & Menirukan & Menirukan & Menirukan \\
\hline
\end{tabular}

Pada tahap observasi atau pengamatan, penulis mengamati secara langsung proses kegiatan latihan tata krama yang dilakukan oleh orang tua. Penulis mencatat setiap proses yang terjadi mulai dari orang tua memberikan contoh, memberikan instruksi, membantu anak untuk dapat menirukan dengan baik serta melihat respon anak.

Dalam kegiatan latihan tata krama pada Siklus I ini, pada dasarnya anak dapat menirukan contoh yang diberikan oleh orang tua. Namun pada awal proses ini berlangsung, dapat dilihat juga bahwa anak enggan dalam menirukan mengucap minta tolong karena anak cenderung untuk menarik tangan orang tua untuk mengambil barang yang diinginkan.

Pada Siklus I ini terdapat peningkatan pada pencapaian indikator yaitu orang tua tahu untuk memberikan contoh yang konsisten dan mudah serta instruksi yang jelas agar anak mudah untuk mengingat. Namun masih dijumpai juga kekurangan dalam pencapaian indikator meskipun pada dasarnya orang tua sudah berusaha untuk melakukan. Kekurangan yang ditemukan dalam siklus I ini antara lain orang tua masih kurang mengkomunikasikan tujuan dari materi tata krama secara singkat pada anak sehingga kurang memotivasi anak untuk merespon dengan cepat.

Dari hasil pengamatan kemudian dilakukan refleksi tentang apa yang sudah dicapai dan yang belum dicapai. Hasil refleksi ini dijadikan sebagai acuan untuk memperbaiki hasil pada siklus II. Diharapkan pemahaman orang tua dapat mencapai hasil yang optimal pada siklus II dengan perbaikan yang akan dilakukan.

Pelaksanaan siklus II dilakukan pada 21 Oktober sampai 29 Nopember 2019 di tempat dan waktu yang sama dengan pelaksanaan siklus I. Perencanaan pada siklus I dipakai lagi pada pelaksanaan siklus II ini dengan mengingat untuk melakukan perbaikan sesuai dengan refleksi pada siklus I. Pelaksanaan pada siklus II ini lebih ditekankan pada indikator yang belum tercapai dengan baik pada siklus I. Proses kegiatan latihan tata krama juga masih sama dengan siklus I dengan penekanan pada indikator yang masih mengalami kekurangan pada siklus I. Pengamatan juga masih dilakukan penulis untuk mendapatkan catatan perkembangan atau peningkatan pada pelaksanaan siklus II ini. 


\section{JPPM (Jurnal Pendidikan dan Pemberdayaan Masyarakat), 7 (1), 2020 - 63}

Dian Ngesti Swandari, Mumpuniarti Mumpuniarti

Setelah pelaksanaan kegiatan latihan tata krama, kembali dilakukan refleksi yang dilakukan oleh penulis bersama guru dan orang tua untuk melihat pencapaian pemahaman orang tua dalam melatih tata krama pada anak autis pada siklus II.

Dalam kegiatan latihan tata krama pada siklus II ini, anak dapat menirukan contoh tata krama dengan baik dan anak mulai dapat merespon dengan tepat.

Hasil dari refleksi siklus II menunjukkan adanya peningkatan yang dilakukan oleh orang tua pada indikator yang kurang pada siklus I. Hal ini berarti kekurangan yang dijumpai pada pada siklus I dapat diperbaiki pada siklus II dengan menunjukkan hasil yang optimal. Hasil dari refleksi ini juga menunjukkan bahwa target yang ditetapkan oleh penulis sudah tercapai yaitu indikator-indikator yang ditentukan dalam pelaksanaan latihan tata krama menggunakan teknik pembelajaran observasional yang menitikberatkan pada pemodelan (modeling) telah mencapai hasil optimal dan tidak perlu dilakukan lagi siklus atau tindakan berikutnya. Pada siklus II ini semua anak dapat menirukan perilaku yang dicontohkan oleh orang tua dan hanya membutuhkan sedikit instruksi untuk membantu mengingat apa yang harus dilakukan.

Dari penelitian ini ditemukan bahwa peran aktif orang tua dalam memberi contoh pada anak tentang tata krama dapat membantu anak untuk lebih cepat memahami dan menirukan materi yang diberikan atau dicontohkan. Temuan ini sesuai dengan teori pembelajaran observasional bahwa pemodelan atau contoh dengan melibatkan atensi (perhatian), retensi (pengingatan), reproduksi (pembentukan perilaku) dan motivasi maka seorang individu dapat lebih mudah melakukan suatu kegiatan seperti yang dicontohkan.

Penelitian ini mendapat hasil yang langsung dapat dilihat dan diterapkan karena semua pihak berperan langsung dan dilibatkan. Sesuai dengan tujuan utama penelitian tindakan yaitu meningkatkan dan melibatkan, penelitian tindakan dimaksudkan untuk mengembangkan keterampilan atau pendekatan baru dan untuk memecahkan masalah dengan penerapan langsung pada situasi tertentu (Madya, 2011, p. 25). Dalam penelitian yang telah dilakukan dapat dilihat bahwa orang tua, anak, guru dan penulis bersama-sama terlibat dari proses awal hingga akhir sehingga semua pihak dapat melihat dan mengalami perubahan maupun peningkatan atau perkembangan yang terjadi selama penelitian.

\section{SIMPULAN}

Pemahaman orang tua dalam membimbing tata krama pada anak autis dengan menggunakan teknik pembelajaran observasional menunjukkan hasil yang lebih baik. Orang tua dapat memahami bahwa mereka memiliki peran yang sangat penting dalam pembelajaran tata krama pada anak autis lewat contoh yang mereka berikan. Penggunaan contoh yang mudah dan konsisten, instruksi yang jelas dan mengkomunikasikan tujuan dari tiap materi tata krama ternyata dapat membantu anak autis untuk lebih mudah menirukan dan mengingat dengan baik latihan yang diberikan.

\section{DAFTAR PUSTAKA}

Anwar, C. (2017). Teori-teori pendidikan klasik hingga kontemporer. IRCiSoD.

Delphie, B. (2009). Pendidikan anak autistik. PT Intan Sejati.

Desmita, D. (2012). Psikologi perkembangan peserta didik. Rosdakarya.

Halle, S., Ninness, C., Ninness, S. K., \& Lawson, D. (2016). Teaching social skills to students with autism: A video modeling social stories approach. Behavior and Social Issues, 25(1), 42-54. https://doi.org/10.5210/bsi.v25io.619o

Helmawati, H. (2017). Pendidik sebagai model menjadikan anak sehat, beriman, cerdas dan berakhlak mulia. Rosda.

Inbar, O., \& Meyer, J. (2019). Politeness counts: Perceptions of peacekeeping robots. IEEE Transactions on Human-Machine Systems, 49(3), 232-240. https://doi.org/10.1109/THMS.2019.2900337 
JPPM (Jurnal Pendidikan dan Pemberdayaan Masyarakat), 7 (1), 2020 - 64

Dian Ngesti Swandari, Mumpuniarti Mumpuniarti

Lordo, D. N., Bertolin, M., Sudikoff, E. L., Keith, C., Braddock, B., \& Kaufman, D. A. S. (2017). Parents perceive improvements in socio-emotional functioning in adolescents with ASD following social skills treatment. Journal of Autism and Developmental Disorders, 47(1), 203-214. https://doi.org/10.1007/s10803-016-2969-o

Madya, S. (2011). Penelitian tindakan (action research). Alfabeta.

Nugraheni, S. A. (2008). Sekilas tentang belantara autisme. Pustaka Zaman.

Okada, S., Ohtake, Y., \& Yanagihara, M. (2010). Improving the manners of a student with autism: The effects of manipulating perspective holders in Social Stories ${ }^{\mathrm{TM}}$ - A pilot study. International Journal of Disability, Development and Education, 57(2), 207-219. https://doi.org/10.108o/10349121003750927

Setyaningrum, Y., Rosiana Masithoh, A., \& Zulia Alfijannah, I. (2018). Hubungan dukungan sosial dengan kemampuan sosialisasi anak autisme di Yayasan Pondok Pesantren ABK Al-Achsaniyyah Kudus tahun 2017. Jurnal Ilmu Keperawatan Dan Kebidanan, 9(1), 44-50. https://doi.org/10.26751/jikk.v9i1.399 